\title{
Finite Element Analysis of Thermoelastic Fiber-Reinforced Anisotropic Hollow Cylinder with Dual-Phase-Lag Model
}

\author{
A. D. Hobiny, ${ }^{a, 1}$ I. A. Abbas, ${ }^{a, b, 2,3}$ and F. Berto ${ }^{c}$ \\ ${ }^{a}$ Nonlinear Analysis and Applied Mathematics Research Group (NAAM), Department of Mathematics, \\ King Abdulaziz University, Jeddah, Saudi Arabia \\ ${ }^{\mathrm{b}}$ Department of Mathematics, Faculty of Science, Sohag University, Sohag, Egypt \\ ${ }^{c}$ Department of Engineering Design and Materials, Norwegian University of Science and Technology \\ (NTNU), Trondheim, Norway \\ 1 ahobany@kau.edu.sa \\ 2 ibrabbas7@science.sohag.edu.eg \\ 3 ibrabbas7@gmail.com
}

УДК 539.4

\section{Скінченноелементний аналіз термопружного армованого волокнами анізотропного порожнистого циліндра на основі моделі двофазного запізнювання}

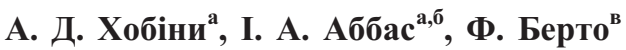 \\ a Дослідницька група 3 нелінійного аналізу та прикладної математики, Відділення мате- \\ матики, Університет короля Абдулазіза, Джидда, Саудівська Аравія \\ ${ }^{\sigma}$ Відділення математики, Технічний факультет, Університет Сохаг, Сохаг, Сгипет \\ в Факультет технічного проектування та матеріалів, Норвезький університет природних i \\ технічних наук, Тронхейм, Норвегія
}

Побудовано рівняння для узагальненої термопружності армованого волокнами анізотропного порожнистого ичиліндра на основі моделі двофазного запізнювання. Досліджується порожнистий циліндр із теплоізольованою ненавантаженою зовнішньою поверхнею, в той час як ненавантажена внутрішня поверхня піддається тепловому удару. Задачу розв'язано чисельно з використанням методу скінченних елементів. Отримані результати для переміщень, температури, радіальних $i$ колових напружень подано графічно. Проведено порівняння між спрогнозованими результатами за зв'язаною теорією термопружності, теорією ЛордаШульмана та за моделлю двофазного запізнювання при наявності і відсутності армування.

Ключові слова: модель двофазного запізнювання, армування волокнами, теорія Лорда-Шульмана, метод скінченних елементів.

Introduction. Materials such as resins reinforced by strong aligned fibers exhibit highly anisotropic elastic behavior in the sense that their elastic moduli for extension in the fiber direction are frequently of the order of 50 or more times greater than their elastic moduli in transverse extension or in shear. Due to their low weight and high strength, the fiber-reinforced composites are used in a variety of structures. The mechanical behavior of many fiber-reinforced composite materials is adequately modelled by the theory of linear elasticity for transversely isotropic materials, with the preferred direction coinciding with the fiber direction. The theory of strongly anisotropic materials has been widely discussed 
in the literature, Belfield et al. [1] investigated the stress in plates reinforced by fibers lying in concentric circles. Hashin and Rosen [2] studied the elastic moduli for fiber-reinforced materials.

The first of such modeling is the extended thermoelasticity theory of Lord and Shulman [3], who introduced the concept of thermal relaxation time into the classical Fourier law of heat conduction. Subsequently, modifying the stress versus strain relationship as well as the entropy relationship with relaxation time, Green and Lindsay [4] proposed the temperature rate-dependent thermoelasticity (GL) theory. The theory was extended for anisotropic body by Dhaliwal and Sherief [5]. Tzou [6, 7] proposed the dual-phase-lag (DPL) model, which describes the interactions between phonons and electrons on the microscopic level as retarding sources causing a delayed response on the macroscopic scale. The DPL model proposed by Tzou [8] is such a modification of the classical thermoelastic model in which the Fourier law is replaced by an approximation to a modified Fourier law with two different time translations: a phase-lag of the heat flux $t_{q}$ and a phase-lag of temperature gradient $t_{\theta}$. Abouelregal [9] studied a problem of a semi-infinite medium subjected to exponential heating using a dual-phase-lag thermoelastic model. Verma [10] studied the shear waves in self-reinforced bodies. Singh [11] discussed the wave propagation in thermally conducting linear fiber-reinforced composite materials with one relaxation time. Othman and Abbas [12] studied the effect of rotation on plane waves at the free surface of a fiber-reinforced thermoelastic halfspace. Abbas [13] investigated the effect of magnetic field on thermoelastic interaction in a fiber-reinforced anisotropic hollow cylinder. Chattopadhyay and Choudhury [14] investigated the propagation, reflection and transmission of magnetoelastic shear waves in a self-reinforced media. Chattopadhyay and Choudhury [15] studied the propagation of magnetoelastic shear waves in an infinite self-reinforced plate. Tian et al. [16], Abbas et. al [17-23], applied the finite element method in different generalized thermoelastic problems.

In the present paper, we have considered a problem of dual-phase-lag model on generalized thermoelasticity of a fiber-reinforced anisotropic hollow cylinder. The problem has been solved numerically using a finite element method (FEM). Numerical results for the temperature distribution, displacement, radial stress and hoop stress are represented graphically. The results indicate that the different between the coupled theory (CT), Lord and Shulman (LS) theory, and DPL model are very pronounced.

Basic Equations and Formulation of the Problem. For a fiber-reinforced linearly thermoelastic anisotropic medium, the constitutive equations preferred to whose direction is that of a unit vector a [11]:

$$
\begin{gathered}
\tau_{i j}=\lambda e_{k k} \delta_{i j}+2 \mu_{T} e_{i j}+\alpha\left(a_{k} a_{m} e_{k m} \delta_{i j}+a_{i} a_{j} e_{k k}\right)+2\left(\mu_{L}-\mu_{T}\right)\left(a_{i} a_{k} e_{k j}+a_{j} a_{k} e_{k i}\right)+ \\
+\beta a_{k} a_{m} e_{k m} a_{i} a_{j}-\beta_{i j}\left(T-T_{0}\right) \delta_{i j}, \quad i, j, k, m=1,2,3 \\
e_{i j}=\frac{1}{2}\left(u_{i, j}+u_{j, i}\right), \quad i, j=1,2,3 .
\end{gathered}
$$

The equation of heat conduction under DPL model [9]

$$
\left(1+t_{\theta} \frac{\partial}{\partial t}\right)\left(K_{i j} T_{i j}\right)=\left(1+t_{q} \frac{\partial}{\partial t}\right)\left(\rho c_{e} \dot{T}+T_{0} \beta_{i j} \dot{u}_{i, j}\right), \quad i, j=1,2,3 .
$$

The equation of motion

$$
\tau_{i j, j}+F_{i}=\rho \ddot{u}_{i}, \quad i, j=1,2,3 .
$$


Three cases arise:

(i) classical dynamical coupled theory

$$
t_{\theta}=t_{q}=0
$$

(ii) LS theory

$$
t_{\theta}=t_{0}>0, \quad t_{q}=0
$$

(iii) DPL model

$$
0<t_{\theta}<t_{q}
$$

where $u_{i}$ are the displacement vector components, $\rho$ is the mass density, $e_{i j}$ is the strain tensor, $T$ is the temperature change of a material particle, $\tau_{i j}$ is the stress tensor, $\beta_{i j}$ is the thermal elastic coupling tensor, $c_{e}$ is the specific heat at constant strain, $T_{0}$ is the reference uniform temperature of the body, $t_{q}$ is a phase-lag of heat flux, $t_{\theta}$ is a phase-lag of temperature gradient, $K_{i j}$ is the thermal conductivity, $\alpha, \beta,\left(\mu_{L}-\mu_{T}\right)$ are reinforced anisotropic elastic parameters, and $\lambda$ and $\mu_{T}$ are elastic parameters and the component of the vector a are $\left(a_{1}, a_{2}, a_{3}\right)$, where $a_{1}^{2}+a_{2}^{2}+a_{3}^{2}=1$.

Let us consider a fiber-reinforced hollow cylinder with an external radius $b$ and internal radius $a$. By using the cylindrical system of coordinates $(r, \theta, z)$ with the $z$-axis lying along the axis of the cylinder. Due to symmetry, the displacement vector has the components

$$
u_{r}=u(r, t), \quad u_{\theta}(r, t)=0, \quad u_{z}(r, t)=0 .
$$

For circumferential reinforcement, the equation of motion in the absence of body forces is given by

$$
\frac{\partial \tau_{r r}}{\partial r}+\frac{1}{r}\left(\tau_{r r}-\tau_{\theta \theta}\right)=\rho \frac{\partial^{2} u}{\partial t^{2}} .
$$

The energy equation without heat sources has the form

$$
\left(1+t_{\theta} \frac{\partial}{\partial t}\right)\left(K_{11} \frac{\partial^{2} T}{\partial r^{2}}+K_{22} \frac{1}{r} \frac{\partial T}{\partial r}\right)=\left(\frac{\partial}{\partial t}+t_{q} \frac{\partial^{2}}{\partial t^{2}}\right)\left(\rho c_{e} T+T_{0} \beta_{11} \frac{\partial u}{\partial r}+T_{0} \beta_{22} \frac{u}{r}\right),
$$

with

$$
\begin{gathered}
\tau_{r r}=\left(\lambda+2 \mu_{T}\right) \frac{\partial u}{\partial r}+(\lambda+\alpha) \frac{u}{r}-\beta_{11}\left(T-T_{0}\right), \\
\tau_{\theta \theta}=(\lambda+\alpha) \frac{\partial u}{\partial r}+\left(\lambda+2 \alpha+4 \mu_{L}-2 \mu_{T}+\beta\right) \frac{u}{r}-\beta_{22}\left(T-T_{0}\right),
\end{gathered}
$$

where

$$
\beta_{11}=2\left(\lambda+\mu_{T}\right) \alpha_{11}+(\lambda+\alpha) \alpha_{22}, \quad \beta_{22}=2(\lambda+\alpha) \alpha_{11}+\left(\lambda+2 \alpha+4 \mu_{L}-2 \mu_{T}+\beta\right) \alpha_{22},
$$

and $\alpha_{11}$ and $\alpha_{22}$ are coefficients of linear thermal expansion. It is convenient to change the preceding equations into the dimensionless forms. To do this, the dimensionless parameters are introduced as

$$
\left(t^{\prime}, t_{\theta}^{\prime}, t_{q}^{\prime}\right)=c_{1}^{2} \chi\left(t, t_{\theta}, t_{q}\right), \quad\left(r^{\prime}, u^{\prime}\right)=c_{1} \chi(r, u), \quad\left(\tau_{r r}^{\prime}, \tau_{\theta \theta}\right)=\frac{1}{A}\left(\tau_{r r}, \tau_{\theta \theta}\right),
$$




$$
T^{\prime}=\frac{T-T_{0}}{T_{0}}, \quad c_{1}=\sqrt{\frac{A}{\rho}}, \quad \chi=\frac{\rho c_{e}}{K_{11}}, \quad A=\lambda+2 \alpha+4 \mu_{L}-2 \mu_{T}+\beta .
$$

From Eqs. (10) into Eqs. (6)-(9) one may obtain (after dropping the superscript ' for convenience)

$$
\begin{gathered}
\left(1+t_{\theta} \frac{\partial}{\partial t}\right)\left(\frac{\partial^{2} T}{\partial r^{2}}+\varepsilon_{1} \frac{1}{r} \frac{\partial T}{\partial r}\right)=\left(\frac{\partial}{\partial t}+t_{q} \frac{\partial^{2}}{\partial t^{2}}\right)\left(T+\varepsilon_{2} \frac{\partial u}{\partial r}+\varepsilon_{3} \frac{u}{r}\right) \\
S_{1}\left(\frac{\partial^{2} u}{\partial r^{2}}+\frac{1}{r} \frac{\partial u}{\partial r}\right)-\frac{u}{r^{2}}-S_{2} \frac{\partial T}{\partial r}-\left(S_{3}-S_{4}\right) \frac{T}{r}=\frac{\partial^{2} u}{\partial t^{2}} \\
\tau_{r r}=S_{1} \frac{\partial u}{\partial r}+S_{2} \frac{u}{r}-S_{3} T \\
\tau_{\theta \theta}=S_{2} \frac{\partial u}{\partial r}+\frac{u}{r}-S_{4} T
\end{gathered}
$$

where

$$
\begin{gathered}
\left(S_{1}, S_{2}, S_{3}, S_{4}\right)=\frac{1}{A}\left(\lambda+2 \mu_{T}, \lambda+\alpha, T_{0} \beta_{11}, T_{0} \beta_{22}\right), \\
\left(\varepsilon_{1}, \varepsilon_{2}, \varepsilon_{3}\right)=\left(\frac{K_{22}}{K_{11}}, \frac{\beta_{11}}{\rho c_{e}}, \frac{\beta_{22}}{\rho c_{e}}\right) .
\end{gathered}
$$

From preceding description, the initial and boundary conditions may be expressed as

$$
\begin{gathered}
u(r, 0)=\frac{\partial u(r, 0)}{\partial t}=0, \quad T(r, 0)=\frac{\partial T(r, 0)}{\partial t}=0, \\
\tau_{r r}(a, t)=0, \quad \tau_{r r}(b, t)=0, \quad T(a, t)=T_{1} H(t), \quad \frac{\partial T(b, t)}{\partial r}=0,
\end{gathered}
$$

where $a$ and $b$ are inner and outer radii of the hollow cylinder, respectively, and $H(t)$ is the Heaviside unit step function.

Finite Element Method. The FEM is a powerful technique originally developed for the numerical solution of complex problems in structural mechanics, and it remains the method of choice for complex systems. In this section, the governing equations of generalized thermoelasticity with dual-phase-lag are summarized, using the corresponding finite element equations. In the FEM, the three isoperimetric, quadrilateral element is used for displacement and temperature. Thus, the displacement component $u$ and temperature $T$ are related to the corresponding nodal values by

$$
u=\sum_{i=1}^{m} N_{i} u_{i}(t), \quad T=\sum_{i=1}^{m} N_{i} T_{i}(t),
$$


where $m$ denotes the number of nodes per element, and $N$ the shape functions. In the framework of standard Galerkin procedure, the weighting functions and the shape functions coincide:

$$
\begin{array}{cc}
\delta u=\sum_{i=1}^{m} N_{i} \delta u_{i}, & \delta T=\sum_{i=1}^{m} N_{i} \delta T_{i}, \\
u^{\prime}=\sum_{i=1}^{m} N_{i}^{\prime} u_{i}(t), & T^{\prime}=\sum_{i=1}^{m} N_{i}^{\prime} T_{i}(t), \\
\delta u^{\prime}=\sum_{i=1}^{m} N_{i}^{\prime} \delta u_{i}, & \delta T^{\prime}=\sum_{i=1}^{m} N_{i}^{\prime} \delta T_{i} .
\end{array}
$$

Thus, Eqs. (11) and (12) corresponding to the finite element equations can be written as

$$
\sum_{e=1}^{m e}\left(\left[\begin{array}{cc}
M_{11}^{e} & 0 \\
M_{21}^{e} & M_{22}^{e}
\end{array}\right]\left\{\begin{array}{l}
\ddot{u}^{e} \\
\ddot{T}^{e}
\end{array}\right\}+\left[\begin{array}{cc}
0 & 0 \\
C_{21}^{e} & C_{22}^{e}
\end{array}\right]\left\{\begin{array}{l}
\dot{u}^{e} \\
\dot{T}^{e}
\end{array}\right\}+\left[\begin{array}{cc}
K_{11}^{e} & K_{12}^{e} \\
0 & K_{22}^{e}
\end{array}\right]\left\{\begin{array}{l}
u^{e} \\
T^{e}
\end{array}\right\}=\left\{\begin{array}{l}
F_{1}^{e} \\
F_{2}^{e}
\end{array}\right\}\right),
$$

where $m e$ is the total number of elements. Appendix presented the coefficients of Eq. (21).

The matrix form of Eq. (21) can be written as

$$
M \ddot{d}+C \dot{d}+K d=F^{e x t},
$$

where $d=\left[\begin{array}{ll}u & T\end{array}\right]^{T}, F^{\text {ext }}, M, C$, and $K$ represent external force vectors, the mass, damping, and stiffness matrices, respectively. Finally, the Newmark time integration method or other methods have to be used to determine the time derivatives of the unknown variables (see [24]).

Numerical Example. To study the effect of reinforcement on wave propagation, we use the following physical constants for generalized fiber-reinforced thermoelastic materials [11]: $\rho=2660 \mathrm{~kg} / \mathrm{m}^{3}, \lambda=5.65 \cdot 10^{10} \mathrm{~N} / \mathrm{m}^{2}, \mu_{T}=2.46 \cdot 10^{10} \mathrm{~N} / \mathrm{m}^{2}, \mu_{L}=5.66 \cdot 10^{10} \mathrm{~N} / \mathrm{m}^{2}$, $\alpha=-1.28 \cdot 10^{10} \mathrm{~N} / \mathrm{m}^{2}, \beta=220.90 \cdot 10^{10} \mathrm{~N} / \mathrm{m}^{2}, \alpha_{11}=0.017 \cdot 10^{-4} \mathrm{deg}-1, T_{1}=1, \alpha_{22}=$ $=0.015 \cdot 10^{-4} \mathrm{deg}^{-1}, c_{e}=0.787 \cdot 10^{3} \mathrm{~J} /(\mathrm{kg} \cdot \mathrm{deg}), T_{0}=293 \mathrm{~K}, t_{q}=0.2, t_{\theta}=0.1, K_{11}=$ $=0.0921 \cdot 10^{3} \mathrm{~J} /(\mathrm{m} \cdot \mathrm{s} \cdot \operatorname{deg}), K_{22}=0.0963 \cdot 10^{3} \mathrm{~J} /(\mathrm{m} \cdot \mathrm{s} \cdot \mathrm{deg})$, and $t=0.5$.

These physical quantities are represented and plotted in Figs. 1-8 with respect to radial distance for $T_{1}=1$ and $t=0.5$. Furthermore, all the variables and parameters are taken in non-dimensional forms. In Figs. 1, 3, 5, and 7 refer to thermoelastic solid without reinforcement (NRE), while in Figs. 2, 4, 6, and 8 - with reinforcement (WRE).

From Figs. 1-8 is seen that, there is no significant difference in the value of temperature for WRE and NRE as in Figs. 3 and 4. Figures 1 and 2 show the variation of displacement for NRE and WRE. It is noticed that the displacement is continuous and the displacement gradually decreases with $r$ and is zero at $r=b$. This is also in agreement with the theoretical result where beyond the thermal wave front displacement vanishes. Figures 5 and 6 represent the variation of stress with respect to distance, which we observed that, the stress, always starts from the zero value and terminates at the zero value to obey the boundary conditions. Figures 7 and 8 gives the variation of hoop stress versus $r$. 


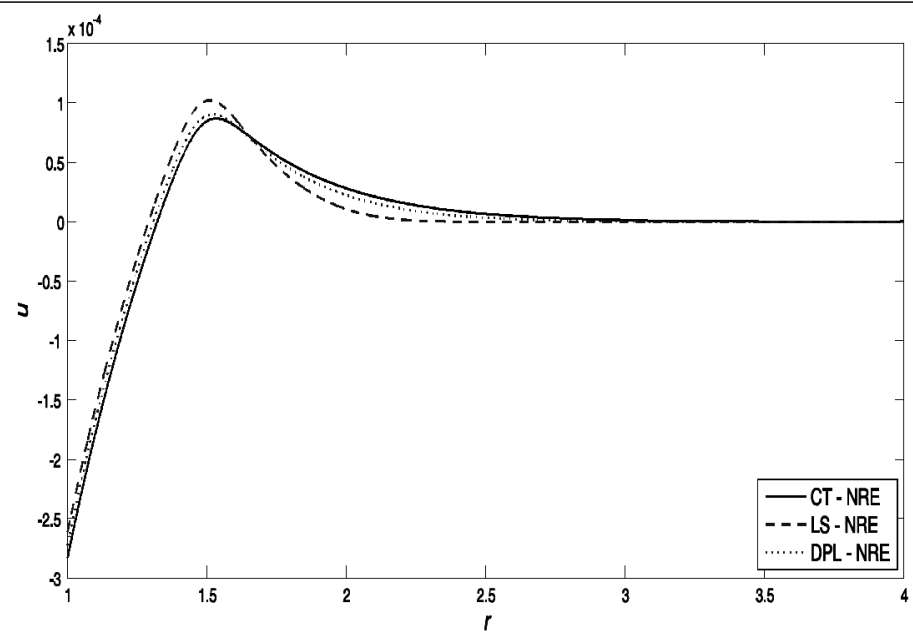

Fig. 1. Displacement distribution for different theories without reinforcement.

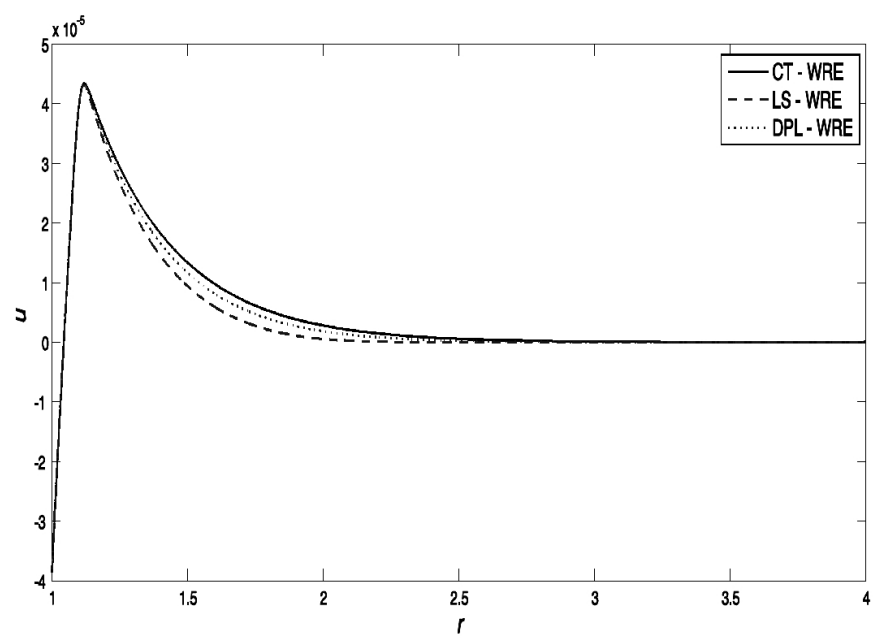

Fig. 2. Displacement distribution for different theories with reinforcement.

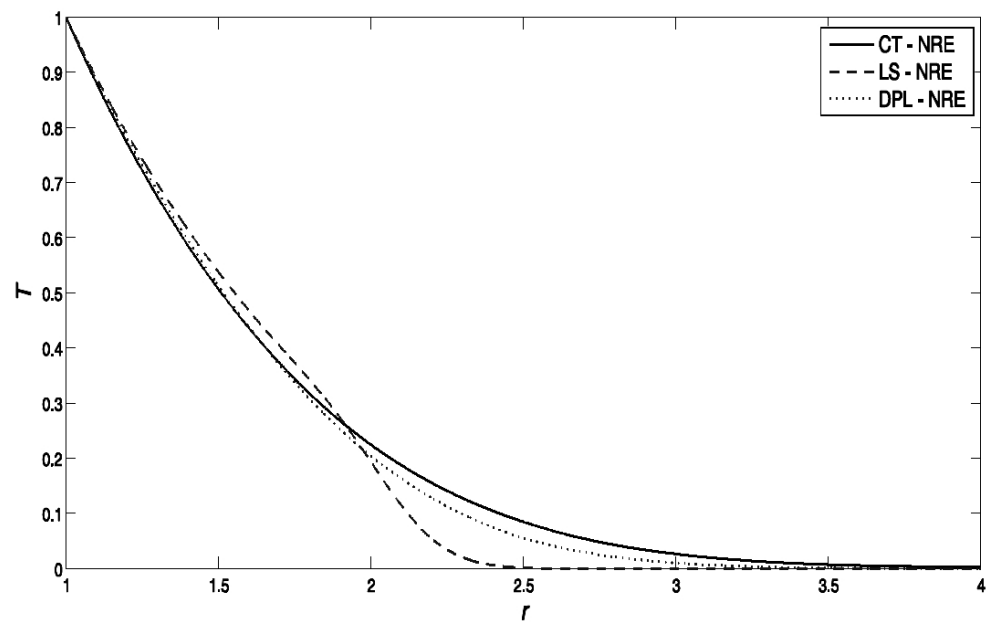

Fig. 3. Temperature distribution for different theories without reinforcement. 


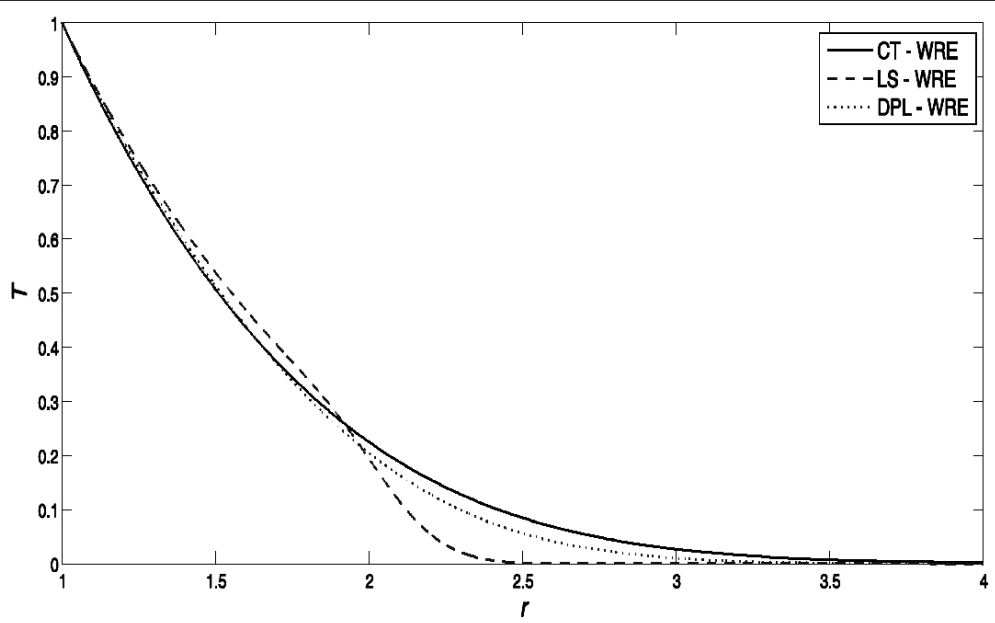

Fig. 4. Temperature distribution for different theories with reinforcement.

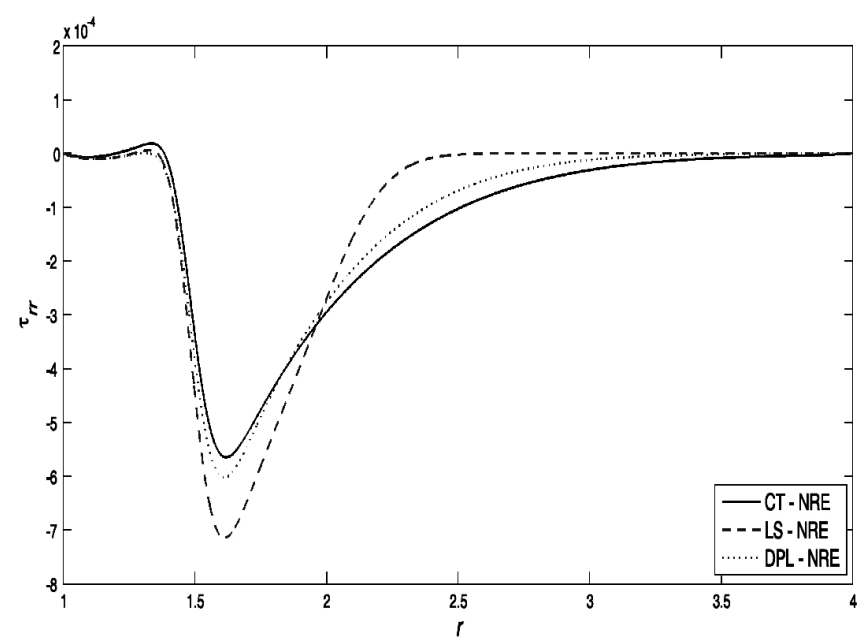

Fig. 5. Radial stress distribution for different theories without reinforcement.

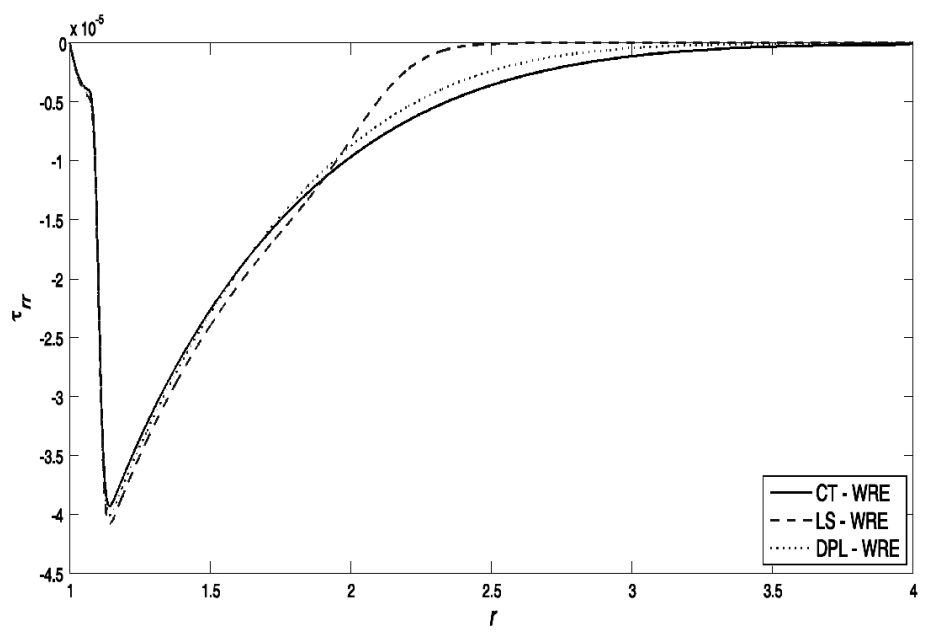

Fig. 6. Radial stress distribution for different theories with reinforcement. 


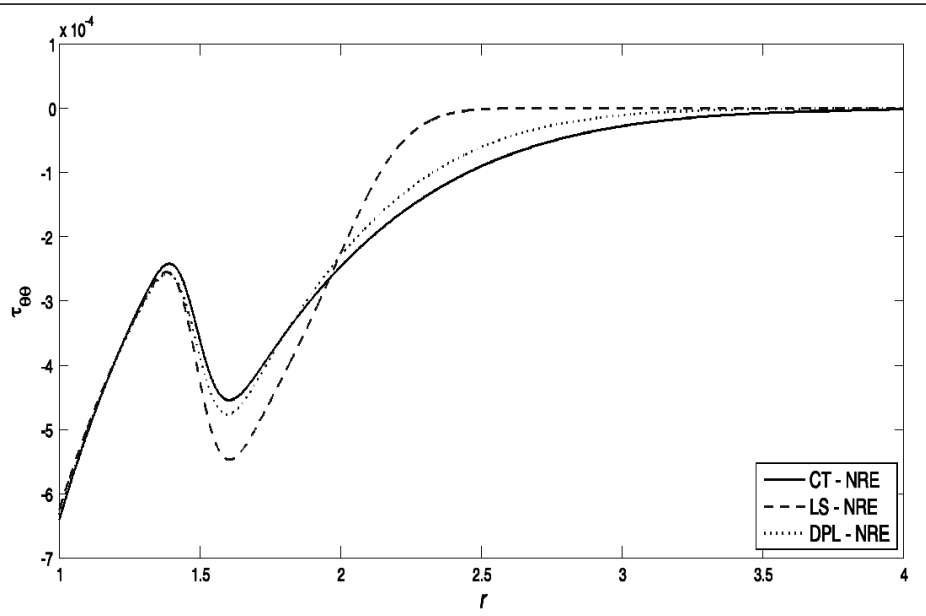

Fig. 7. Hoop stress distribution for different theories without reinforcement.

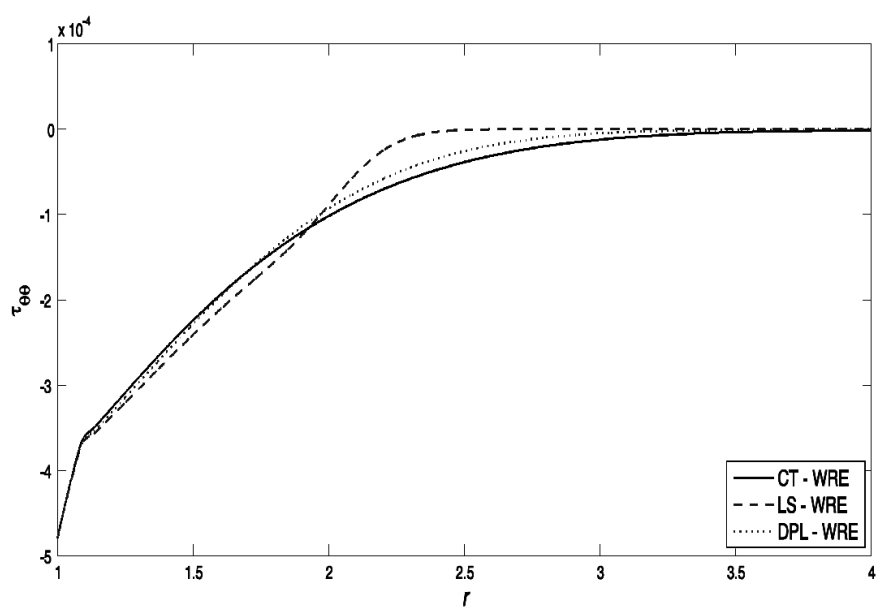

Fig. 8. Hoop stress distribution for different theories with reinforcement.

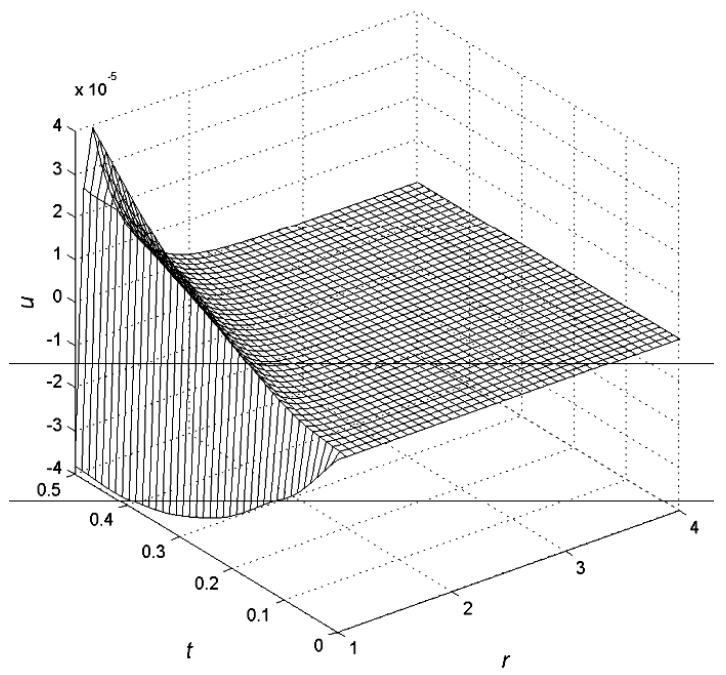

Fig. 9. Displacement distribution with reinforcement. 


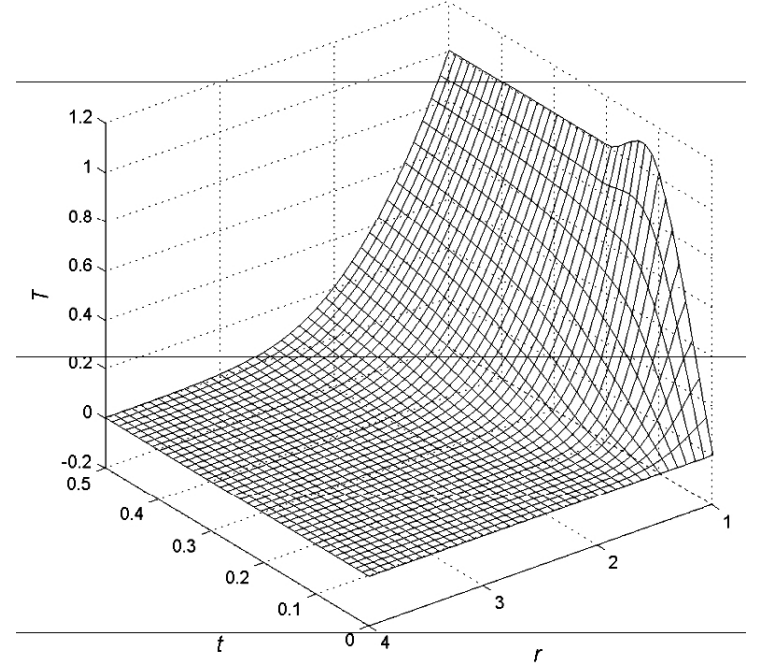

Fig. 10. Temperature distribution with reinforcement.

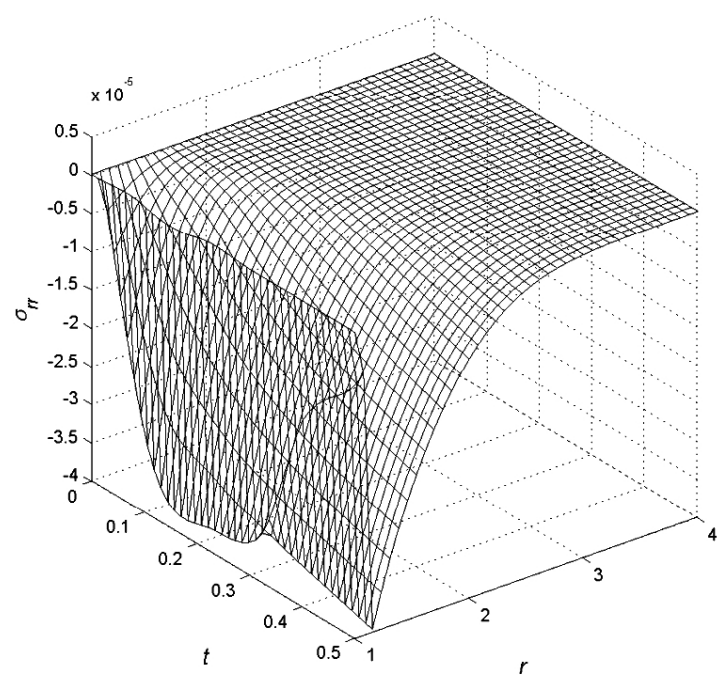

Fig. 11. Radial stress distribution with reinforcement.

Also, for each theory the hoop stress have a maximum magnitude at the boundary. Figures 9 , 10,11 , and 12 display the distribution of the displacement, temperature, radial and hoop stresses for a wide range of $r(1 \leq r \leq 4)$ and for a wide range of dimensionless time $t$ $(0 \leq t \leq 0.5)$. The reinforcement has a great effect on the distribution of displacement and stresses. Finally, it is obvious that the phase-lag parameters $t_{\theta}$ and $t_{q}$ have very pronounced effect on the temperature and displacement, radial and hoop stresses.

Appendix. The coefficients in Eq. (21) are given by

$$
\begin{gathered}
M_{11}^{e}=\int[N]^{T}[N] d r, \quad M_{21}^{e}=\int[N]^{T} t_{q}\left(\varepsilon_{2}\left[N^{\prime}\right]+\frac{\varepsilon_{3}}{r}[N]\right) d r, \quad M_{22}^{e}=\int t_{q}[N]^{T}[N] d r, \\
C_{21}^{e}=\int[N]^{T}\left(\varepsilon_{2}\left[N^{\prime}\right]+\frac{\varepsilon_{3}}{r}[N]\right) d r,
\end{gathered}
$$




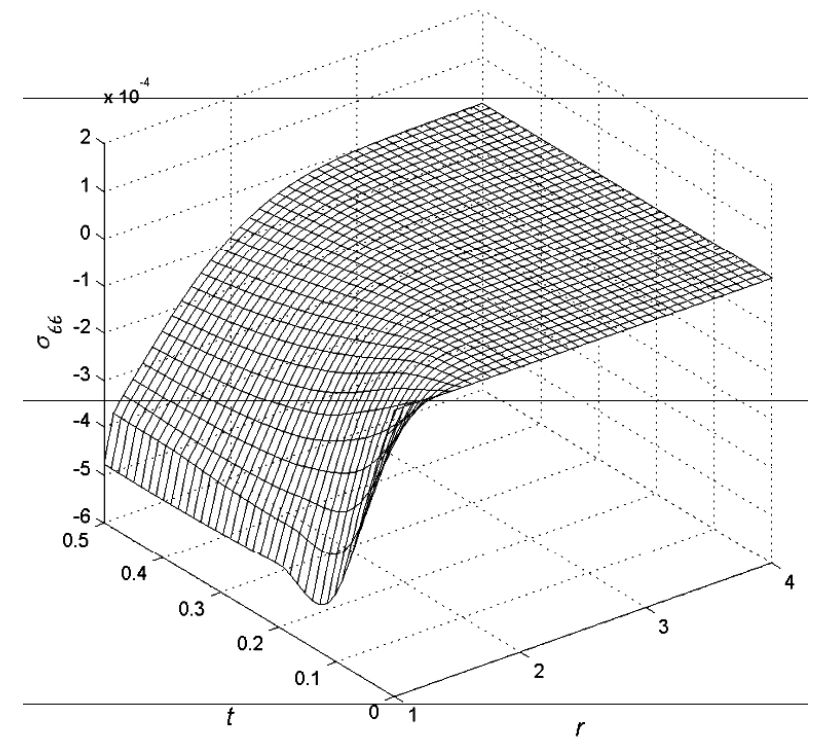

Fig. 12. Hoop stress distribution with reinforcement.

$$
\begin{gathered}
C_{22}^{e}=\int\left(t_{\theta}\left(\left[N^{\prime}\right]^{T}\left[N^{\prime}\right]-\frac{\varepsilon_{1}}{r}[N]^{T}[N]\right)+t_{q}[N]^{T}[N]\right) d r, \\
K_{11}^{e}=\int\left[\left[N^{\prime}\right]^{T}\left(S_{1}\left[N^{\prime}\right]+\frac{S_{2}}{r}[N]\right)-[N]^{T}\left(\frac{S_{1}-S_{2}}{r}\left[N^{\prime}\right]+\frac{S_{2}-1}{r^{2}}[N]\right)\right] d r, \\
K_{12}^{e}=\int\left[-\left[N^{\prime}\right]^{T} S_{3}[N]+\frac{S_{3}-S_{4}}{r}[N]^{T}[N]\right] d r, \quad F_{1}^{e}=\left.[N]^{T} \bar{\tau}\right|_{1} ^{r}, \\
K_{22}^{e}=\int\left[\left[N^{\prime}\right]^{T}\left[N^{\prime}\right]-\frac{\varepsilon_{1}}{r}[N]^{T}[N]\right] d r, \quad F_{2}^{e}=\left.[N]^{T} \bar{q}\right|_{1} ^{r},
\end{gathered}
$$

where $\bar{\tau}$ represent the component of the traction, and $\bar{q}$ represents heat flux.

Acknowledgments. This project was funded by the Deanship of Scientific Research (DSR) at King Abdulaziz University (Jeddah), under Grant No. G/205/130/38. The authors, therefore, acknowledge with thanks DSR for technical and financial support.

\section{Резюме}

Построены уравнения для обобщенной термоупругости армированного волокнами анизотропного полого цилиндра на основе модели двухфазного запаздывания. Исследуется полый цилиндр с теплоизолированной ненагруженной внешней поверхностью, в то время как ненагруженная внутренняя поверхность подвергнута тепловому удару. Задача решена численно с использованием метода конечных элементов. Полученные результаты для перемещения, температуры, радиальных и окружных напряжений представлены графически. Проведено сравнение между прогнозируемыми результатами по связанной теории термоупругости, теории Лорда-Шульмана и по модели двухфазного запаздывания при наличии и отсутствии армирования. 
1. A. J. Belfield, T. G. Rogers, and A. J. M. Spencer, "Stress in elastic plates reinforced by fibres lying in concentric circles," J. Mech. Phys. Solids, 31, No. 1, 25-54 (1983).

2. Z. Hashin and W. B. Rosen, "The elastic moduli of fiber-reinforced materials," $J$. Appl. Mech., 31, 223-232 (1964).

3. H. W. Lord and Y. Shulman, "A generalized dynamical theory of thermoelasticity," $J$. Mech. Phys. Solids, 15, No. 5, 299-309 (1967).

4. A. E. Green and K. A. Lindsay, "Thermoelasticity," J. Elasticity, 2, No. 1, 1-7 (1972).

5. R. S. Dhaliwal and H. H. Sherief, "Generalized thermoelasticity for anisotropic media," Q. Appl. Math., 38, 1-8 (1980).

6. D. Y. Tzou, Macro- to Microscale Heat Transfer: The Lagging Behavior, Taylor \& Francis, Washington (1996).

7. D. Y. Tzou, "A unified approach for heat conduction from macro- to micro-scales," $J$. Heat Transfer, 117, No. 1, 8-16 (1995).

8. D. Y. Tzou, "Experimental support for the lagging behavior in heat propagation," $J$. Thermophys. Heat Tr., 9, No. 4, 686-693 (1995).

9. A. E. Abouelregal, "A problem of a semi-infinite medium subjected to exponential heating using a dual-phase-lag thermoelastic model," Appl. Math., 2, 619-624 (2011).

10. P. D. S. Verma, "Magnetoelastic shear waves in self-reinforced bodies," Int. J. Eng. Sci., 24, No. 7, 1067-1073 (1986).

11. B. Singh, "Wave propagation in in thermally conducting linear fibre-reinforced composite materials," Arch. Appl. Mech., 75, 513-520 (2006).

12. M. I. A. Othman and I. A. Abbas, "Effect of rotation on plane waves at the free surface of a fibre-reinforced thermoelastic half-space using the finite element method," Meccanica, 46, No. 2, 413-421 (2011).

13. I. A. Abbas, "Generalized magneto-thermoelastic interaction in a fiber-reinforced anisotropic hollow cylinder," Int. J. Thermophys., 33, No. 3, 567-579 (2012).

14. A. Chattopadhyay and S. Choudhury, "Propagation, reflection and transmission of magnetoelastic shear waves in a self-reinforced media," Int. J. Eng. Sci., 28, No. 6, 485-495 (1990).

15. A. Chattopadhyay and S. Choudhury, "Magnetoelastic shear waves in an infinite self-reinforced plate," Int. J. Numer. Anal. Met., 19, No. 4, 289-304 (1995).

16. X. Tian, Y. Shen, C. Chen, and T. He, "A direct finite element method study of generalized thermoelastic problems," Int. J. Solids Struct., 43, 2050-2063 (2006).

17. I. A. Abbas and H. M. Youssef, "Finite element analysis of two-temperature generalized magneto-thermoelasticity," Arch. Appl. Mech., 79, No. 10, 917-925 (2009).

18. I. A. Abbas, "Generalized magneto-thermoelasticity in a non-homogeneous isotropic hollow cylinder using finite element method," Arch. Appl. Mech., 79, No. 1, 41-50 (2009).

19. I. A. Abbas and A. N. Abd-alla, "Effects of thermal relaxations on thermoelastic interactions in an infinite orthotropic elastic medium with acylindrical cavity," Arch. Appl. Mech., 78, 283-293 (2008).

20. I. A. Abbas and M. I. A. Othman, "Generalized thermoelasticity of thermal shock problem in an isotropic hollow cylinder and temperature dependent elastic moduli," Chinese Phys. B, 21, No. 1, 014601 (2012). 
21. I. A. Abbas and M. I. A. Othman, "Generalized thermoelasticity of thermal shock problem in a non-homogeneous isotropic hollow cylinder with energy dissipation," Int. J. Thermophys., 33, No. 5, 913-923 (2012).

22. R. Kumar, V. Gupta, and I. A. Abbas, "Plane deformation due to thermal source in fractional order thermoelastic media," J. Comput. Theor. Nanos., 10, No. 10, 25202525 (2013).

23. I. A. Abbas and A. Zenkour, "Two-temperature generalized thermoelastic interaction in an infinite fiber-reinforced anisotropic plate containing a circular cavity with two relaxation times," J. Comput. Theor. Nanos., 11, No. 1, 1-7 (2014).

24. P. Wriggers, Nonlinear Finite Element Methods, Springer, Berlin-Heidelberg (2008).

Received 01. 03. 2017 